\title{
Branched-chain amino acid oxidation in relation to catabolic enzyme activities in rats given a protein-free diet at different stages of development
}

\author{
By R. D. SKETCHER AND W. P. T. JAMES \\ London School of Hygiene and Tropical Medicine, Clinical Nutrition and Metabolism \\ Unit, Hospital for Tropical Diseases, 4 St Pancras Way, London NW I $2 P E$
}

(Received 5 April 1974-Accepted 7 Fune 1974)

\begin{abstract}
1. The capacity of animals to conserve branched-chain amino acids was assessed during 3 weeks on a protein-free (PF) diet in groups of female rats at three stages of development, i.e. at weaning $(35 \mathrm{~g})$, in a period of rapid growth $(85 \mathrm{~g})$ and at maturity $(200 \mathrm{~g})$.

2. Leucine and valine oxidation was assessed by monitoring the evolution of ${ }^{14} \mathrm{CO}_{2}$ from a tracer dose of the $\left[{ }^{I}{ }^{14} \mathrm{C}\right]$-labelled L-amino acid given intragastrically. Activities of the L-leucine:2-ketoglutarate aminotransferase $(E C$ 2.6.I.6) and $\alpha$-keto acid dehydrogenase enzymes in leucine and valine metabolism were also determined in muscle and liver at weekly intervals.

3. All three groups of rats given a normal protein intake excreted the same proportion of the dose of labelled leucine and valine. In rats given PF diet there was a consistent reduction in ${ }^{14} \mathrm{CO}_{2}$ output from both $\mathrm{L}-\left[\mathrm{I}-{ }^{14} \mathrm{C}\right]$ leucine and $\mathrm{L}-\left[\mathrm{I}-{ }^{14} \mathrm{C}\right]$ valine, but valine was not conserved as efficiently as leucine.

4. Muscle dehydrogenase responded to a PF diet in all three groups of rats, but the most marked changes occurred in the youngest group. In addition, there was a decrease in hepatic dehydrogenase activities for leucine and valine catabolism in the weanling group; in older animals there was little change in the $\alpha$-keto-isovalerate, but a consistent decrease in the activity of the $\alpha$-keto-isocaproic acid dehydrogenase. The difference in the responsiveness of the dehydrogenases, therefore, matched the difference between leucine and valine oxidation rates in vivo.

5. Weanling animals responded rather more efficiently than the older animals to the need to conserve amino acids and there was no evidence of a poorly developed system for adapting to $\mathrm{PF}$ intake at this early stage of development.

6. Despite reduced catabolism of the amino acids, aminotransferase activities in liver and muscle rose in the first $\mathrm{I}-2$ weeks on a PF regimen. Aminotransferase activity as such is unlikely to control acid oxidation.
\end{abstract}

McFarlane \& Von Holt (r969a) demonstrated a decreased oxidation of DL$\left[2-{ }^{14} \mathrm{C}\right]$ leucine in rats given a diet containing $20 \mathrm{~g}$ protein $/ \mathrm{kg}$ for 8 weeks. Further studies of theirs (McFarlane \& Von Holt $1969 b$ ) indicated a block in the decarboxylation of leucine with a reduction in the mitochondrial dehydrogenase activity in liver. Mimura, Yamada \& Swendseid ( 1968 ), in studies on muscle, noted an increase in the activity of the branched-chain amino acid transferases in protein-deficient rats but attempts to demonstrate a branched-chain keto-acid dehydrogenase in muscle had failed to show any activity (Wolhueter \& Harper, r970). Recently, however, Featherston \& Horn (1973) have demonstrated dehydrogenase activity in chick muscle.

Several workers have reported oxidation of leucine and valine in muscle preparations implying that muscle has a role in branched-chain amino acid oxidation (Pain $\&$ Manchester, 1970; Buse, Biggers, Friderici \& Buse, 1972; Goldberg, 1972; Ruderman \& Lund, 1972). It has also been suggested that muscle may be the main site for 
leucine oxidation (Young, I970) mainly because of its high aminotransferase activity and the failure to demonstrate significant leucine uptake and oxidation by the liver (Miller, rg62).

We have also shown that a dehydrogenase for leucine catabolism exists in rat muscle and concluded that muscle could account for $90 \%$ of the body's capacity to oxidize the keto acid of leucine (Sketcher, Fern \& James, 1974). Furthermore, changes occurred in dehydrogenase activity in muscle on altering the protein intake which might be related to the control of leucine oxidation.

The present study was designed to determine liver and muscle enzyme activities in rats at different stages of development, and to relate any changes in activity to the ability of rats to reduce the catabolism of leucine and valine on a protein-free ( $\mathrm{PF})$ diet. The study assessed in particular whether animals at weaning were able to adapt to a deficient diet as readily as older animals.

\section{METHODS}

\section{Animals and diets}

Three different groups of female hooded Lister rats were used to investigate the oxidation of leucine and valine and the adaptation in the catabolic enzymes of these two amino acids in animals of different ages when given a PF diet for up to 3 weeks. The first group was obtained at weaning and immediately fed $a d l i b$. on a PF diet. Two other groups of rats were fed initially on a control diet from weaning in which the ratio, energy supplied by utilizable protein:total metabolizable energy (NDp:E) was 0. Io (Payne \& Stewart, 1972). When one group reached a weight of approximately $85 \mathrm{~g}$, the animals were given a PF diet for a further 3 weeks. The last group was maintained on the $0.10 \mathrm{NDp}: \mathrm{E}$ diet until the rats had reached an average weight of $200 \mathrm{~g}$, when they too were given the PF diet.

Control animals received the adequate protein intake, i.e. $0 \cdot 10 \mathrm{NDp}: \mathrm{E}$ diet, throughout and were assessed at weights of 35,85 and $200 \mathrm{~g}$. The O.IO NDp:E diet was based on casein and maize starch with additional methionine to improve the quality of the protein. Details of the diet are given elsewhere (Sketcher et al. 1974). The PF diet contained no casein or methionine; the weight was made up with maize starch so that both diets had the same energy content. All the animals studied were fed until $5 \mathrm{~h}$ before the experiment.

\section{Radioactivity measurements}

$\mathrm{L}-\left[\mathrm{I}-{ }^{14} \mathrm{C}\right]$ leucine was purchased from the Radiochemical Centre, Amersham, Bucks. (specific radioactivity $60 \mathrm{mCi} / \mathrm{mmol}$ ). $\mathrm{L}-\left[\mathrm{I}-{ }^{14} \mathrm{C}\right]$ valine was obtained from Calatomic, Los Angeles, California, USA (specific radioactivity $10 \mathrm{mCi} / \mathrm{mmol}$ ).

The rats were given an intragastric injection of either L-leucine or L-valine with a tracer dose of $\mathrm{L}-\left[\mathrm{r}-{ }^{14} \mathrm{C}\right]$ leucine or $\mathrm{L}-\left[\mathrm{r}-{ }^{14} \mathrm{C}\right]$ valine, respectively ( $\mathrm{Io} \mu \mathrm{Ci} / \mathrm{kg}$ body-weight in a solution of $9 \mathrm{~g} \mathrm{NaCl} / 1$ with Io $\mu \mathrm{mol}$ leucine/ $\mathrm{kg}$ body-weight as carrier), and placed immediately in a sealed vessel through which air was drawn at a constant rate. 
Table I. In vivo oxidation of $\mathrm{L}-\left[\mathrm{r}-{ }^{14} \mathrm{C}\right] l e u c i n e$ and $\mathrm{L}-\left[\mathrm{I}-{ }^{14} C\right]$ valine (10 $\mu C i / k g$ body-wt) in rats given control (O·1O ND $p$ : $\mathrm{E} \dagger)$ and protein-free $(P F)$ diets

(Mean values with their standard errors; number of observations in parentheses)

\begin{tabular}{|c|c|c|c|c|c|c|c|c|}
\hline \multirow{3}{*}{$\begin{array}{l}\text { Group } \\
\text { Weanling }\end{array}$} & \multirow{3}{*}{$\begin{array}{c}\text { Mean } \\
\text { weight } \\
35 \mathrm{~g}\end{array}$} & \multirow{3}{*}{$\begin{array}{c}\text { Time on PF } \\
\text { diet (weeks) } \\
0\end{array}$} & \multicolumn{6}{|c|}{${ }^{14} \mathrm{CO}_{2}$ excretion expressed as $\%$ labelled dose of : } \\
\hline & & & \multicolumn{3}{|c|}{ Leucine } & \multicolumn{3}{|c|}{ Valine } \\
\hline & & & Mean & $\mathrm{SE}$ & & Mean & $\mathrm{SE}$ & \\
\hline Weanling & $35 \mathrm{~g}$ & $\begin{array}{l}0 \\
\text { I } \\
2 \\
3\end{array}$ & $\begin{array}{r}15 \cdot 0 \\
7 \cdot 0 \\
6 \cdot 2 \\
6 \cdot 2\end{array}$ & $\begin{array}{l}0.52 \\
0.57^{* *} \\
0.37^{* *} \\
0.40^{* *}\end{array}$ & $\begin{array}{l}(3) \\
(6) \\
(6) \\
(5)\end{array}$ & $\begin{array}{r}13 \cdot 4 \\
9 \cdot 3 \\
8 \cdot 3 \\
7 \cdot 9\end{array}$ & $\begin{array}{l}0.8 \mathrm{I} \\
0.98^{* *} \\
0.23^{* *} \\
0.64 *\end{array}$ & $\begin{array}{l}(3) \\
(3) \\
(3) \\
(5)\end{array}$ \\
\hline Growing & $85 \mathrm{~g}$ & $\begin{array}{l}0 \\
\text { I } \\
2 \\
3\end{array}$ & $\begin{array}{r}15 \cdot 4 \\
9 \cdot 6 \\
6 \cdot 5 \\
7 \cdot 4\end{array}$ & $\begin{array}{l}2.42 \\
0.57^{* *} \\
0.90 * * \\
0.86 * *\end{array}$ & $\begin{array}{l}(3) \\
(6) \\
(6) \\
(6)\end{array}$ & $\begin{array}{r}14 \cdot 9 \\
7 \cdot 9 \\
8 \cdot 4 \\
9 \cdot 1\end{array}$ & $\begin{array}{l}\mathrm{I} \cdot 79 \\
0.61 * * \\
0.41 * * \\
0.54 * *\end{array}$ & $\begin{array}{l}(3) \\
(6) \\
(6) \\
(5)\end{array}$ \\
\hline Adult & $200 \mathrm{~g}$ & $\begin{array}{l}0 \\
1 \\
2 \\
3\end{array}$ & $\begin{array}{r}14 \cdot 3 \\
8 \cdot 8 \\
9 \cdot 0 \\
9 \cdot 0\end{array}$ & $\begin{array}{l}0.46 \\
0.52^{* *} \\
1.55^{* *} \\
0.17^{* *}\end{array}$ & $\begin{array}{l}(3) \\
(3) \\
(3) \\
(3)\end{array}$ & $\begin{array}{l}15 \cdot 9 \\
11 \cdot 2 \\
10 \cdot 7 \\
-\end{array}$ & $\begin{array}{l}0.87 \\
0.98 * * \\
\times 27^{* *} \\
-\end{array}$ & $\begin{array}{l}(3) \\
(3) \\
(3)\end{array}$ \\
\hline
\end{tabular}

** Values differ significantly from the control value for the group $(P<0.02)$.

$\dagger$ Ratio, energy supplied by utilizable protein: total metabolizable energy.

The $\mathrm{CO}_{2}$ was trapped by techniques previously described (Sketcher et al. 1974). Oxidation within $3 \mathrm{~h}$ was expressed as the percentage of the labelled dose expired as ${ }^{14} \mathrm{CO}_{2}$.

\section{Enzyme assays}

In vitro assays of aminotransferase and dehydrogenase activities were measured in muscle and liver preparations from rats given the same diets as those used for the assessment of oxidation in vivo. Groups of rats were killed by decapitation at weekly intervals and their livers and gastrocnemius muscles were excised and quickly frozen on solid $\mathrm{CO}_{2}$. Four enzyme activities were measured in both tissues:L-leucine:2ketoglutarate aminotransferase ( $E C$ 2.6. I.6), $\alpha$-keto-isocaproic acid dehydrogenase $(\alpha \mathrm{KIC}), \mathrm{L}$-valine:2-ketoglutarate aminotransferase, and $\alpha$-keto-isovalerate dehydrogenase $(\alpha \mathrm{KIV})$. For the assay a weighed amount $(500 \mathrm{mg})$ of liver or muscle tissue was homogenized by hand in ice-cold Sorensen's phosphate buffer $(25 \mathrm{mmol} / \mathrm{l})$ $\mathrm{pH} 7.0$ to give a $\mathrm{I}: \mathrm{IO}(\mathrm{w} / \mathrm{v})$ homogenate. Preliminary studies showed that the use of the Polytron for homogenizing muscle resulted in a total loss of dehydrogenase activity in muscle, but hand homogenization with a Dual glass homogenizer preserved the activity of the enzyme. The enzyme activities were determined by the methods described by Sketcher et al. (1974). Details of all materials and solutions are given elsewhere (Sketcher et al. 1974).

\section{RESULTS}

Table I shows the proportion of labelled leucine and valine expired as $\mathrm{CO}_{2}$ by the three groups of animals. Both weaned and $200 \mathrm{~g}$ animals expired a similar proportion of label. Equivalent amounts of ${ }^{19} \mathrm{CO}_{2}$ were evolved from labelled leucine and valine 
Table 2. Liver enzyme activities in rats given a protein-free $(P F)$ diet; L-leucine:- and L-valine:2-ketoglutarate aminotransferase and $\alpha$-keto-isocaproic acid $(\alpha K I C)$ and $\alpha$-ketoisovaleric acid dehydrogenase $(\alpha K I V)$ activities (nmol amino acid or keto acid oxidized/mg protein per $h$ )

(Mean values with their standard errors for groups of four animals)

\begin{tabular}{|c|c|c|c|c|c|c|c|c|c|c|}
\hline \multirow[b]{3}{*}{ Group } & \multirow{3}{*}{$\begin{array}{c}\text { Mean } \\
\text { weight }\end{array}$} & \multirow{3}{*}{$\begin{array}{l}\text { Time on } \\
\text { PF diet } \\
\text { (weeks) }\end{array}$} & \multicolumn{4}{|c|}{ Leucine } & \multicolumn{4}{|c|}{ Valine } \\
\hline & & & \multicolumn{2}{|c|}{$\begin{array}{l}\text { 2-Ketoglutarate } \\
\text { aminotransferase }\end{array}$} & \multicolumn{2}{|c|}{$\underset{\sim}{\alpha \mathrm{KIC}}$} & \multicolumn{2}{|c|}{$\begin{array}{l}\text { 2-Ketoglutarate } \\
\text { aminotransferase }\end{array}$} & \multicolumn{2}{|c|}{$\alpha \mathrm{KIV}$} \\
\hline & & & Mean & $\mathrm{SE}$ & Mean & $\mathrm{SE}$ & Mean & $\mathrm{SE}$ & Mean & $\mathrm{SE}$ \\
\hline \multirow[t]{4}{*}{ Weanling } & $35 \mathrm{~g}$ & $\circ$ & $8 \cdot 6$ & 0.8 & 3.5 & 0.45 & $5 \cdot 5$ & 0.7 & $2 \cdot 8$ & 0.7 \\
\hline & & $\mathbf{I}$ & 14.5 & $3 \cdot 5$ & $2 \cdot 2$ & 0.60 & I $8 \cdot 0$ & $3 \cdot 5 *$ & $r \cdot 9$ & 0.25 \\
\hline & & 2 & $12 \cdot 2$ & $0.7^{*}$ & $2 \cdot 2$ & 0.45 & $22 \cdot 3$ & $0.5^{*}$ & $I \cdot 2$ & 0.10 \\
\hline & & 3 & 10.9 & I.05 & 0.8 & $0.20 *$ & - & - & 0.4 & $0.05^{*}$ \\
\hline \multirow[t]{4}{*}{ Growing } & $85 \mathrm{~g}$ & $\circ$ & $7 \cdot 0$ & $0 \cdot 6$ & $x \cdot 8$ & $0 \cdot 1$ & $3 \cdot 0$ & 0.35 & 0.9 & 0.05 \\
\hline & & $\mathbf{I}$ & $12 \cdot I$ & $0.9^{*}$ & $I \cdot 3$ & 0.2 & $2 I \cdot 0$ & $0.5 *$ & 0.9 & 0.35 \\
\hline & & 2 & - & - & - & - & 一 & - & - & - \\
\hline & & 3 & $8 \cdot 9$ & $0.45^{*}$ & 0.6 & $0 . I^{*}$ & $4^{\circ} 9$ & $0.25^{*}$ & $I \cdot 2$ & $0.05^{*}$ \\
\hline \multirow[t]{4}{*}{ Adult } & $200 \mathrm{~g}$ & 0 & $7 \cdot 8$ & 0.6 & $I \cdot 2$ & 0.065 & $3 \cdot I$ & 0.65 & $I \cdot 6$ & $O . I$ \\
\hline & & $\mathbf{r}$ & 10.4 & 0.9 & $I^{\circ} O$ & 0.06 & $7 \cdot 1$ & $0.6^{*}$ & $I \cdot 4$ & 0.075 \\
\hline & & 2 & $6 \cdot 6$ & 0.7 & 0.8 & $0.045^{*}$ & $6 \cdot 1$ & $0.6^{*}$ & $I \cdot I$ & $0.045^{*}$ \\
\hline & & 3 & $6 \cdot 3$ & 0.15 & $1 \cdot 0$ & $0.04^{*}$ & $3 \cdot 3$ & 0.35 & $I \cdot 2$ & $0.04^{*}$ \\
\hline
\end{tabular}

* Values differ significantly from the control value for the group $(P<0.05)$.

in those animals given a normal diet and the individual values within groups were very consistent.

Feeding on a PF diet led to a decrease in oxidation rates in all three age-groups. The response to a PF diet occurred early in the feeding regimen, since the greatest decrease in ${ }^{14} \mathrm{CO}_{2}$ excretion occurred within the first week; thereafter further decreases in the catabolism of either $\mathrm{L}-\left[\mathrm{I}-{ }^{14} \mathrm{C}\right]$ leucine or $\mathrm{L}-\left[\mathrm{I}-{ }^{14} \mathrm{C}\right]$ valine were small (Table $\mathrm{I}$ ). There was a tendency for the youngest group of animals to have the greatest decrease in ${ }^{14} \mathrm{CO}_{2}$ output, e.g. there was a $59 \%$ decrease in leucine oxidation in the weanling rats compared with a decrease of $37 \%$ in the mature group. The adaptation in valine oxidation seemed less effective than that for leucine, with higher excretion rates of ${ }^{14} \mathrm{CO}_{2}$ from $\mathrm{L}-\left[\mathrm{I}-{ }^{14} \mathrm{C}\right]$ valine in rats on the low-protein diet.

Results obtained for determinations of liver enzyme activities suggest that in the control animals the weanling rats had higher aminotransferase and dehydrogenase activities (Table 2). The dehydrogenase responsible for leucine catabolism decreased in all animals within $\mathrm{I}$ week and a further reduction in liver oxidation capacity occurred as the $\mathrm{PF}$ regimen continued. As with the in vivo measurements of leucine oxidation, the decrease in enzyme activity was most marked in the weanling rats. The liver activities of $\alpha \mathrm{KIV}$ showed a marked reduction only in the weanling group.

In contrast to the decrease in dehydrogenase activities, the aminotransferase levels in liver increased in rats given a PF diet (Table 2). Large increases were often seen, e.g. in L-valine:2-ketoglutarate aminotransferase in the younger animals. A further difference between the response in aminotransferase and dehydrogenase activities 
Table 3. Gastrocnemius muscle enzyme activities in rats given a protein-free $\left(P F^{\prime}\right)$ diet: L-leucine:- and L-valine:2-ketoglutarate aminotransferase and $\alpha$-keto-isocaproic acid $(\alpha K I C)$ and $\alpha$-keto-isovaleric acid $(\alpha K I V)$ dehydrogenase activities (nmol leucine or valine or the corresponding keto acid oxidized/mg protein per $h$ )

(Mean values with their standard errors for groups of four animals)

\begin{tabular}{|c|c|c|c|c|c|c|c|c|c|c|}
\hline \multirow[b]{3}{*}{ Group } & \multirow{3}{*}{$\begin{array}{c}\text { Mean } \\
\text { weight }\end{array}$} & \multirow{3}{*}{$\begin{array}{l}\text { Time on } \\
\text { PF diet } \\
\text { (weeks) }\end{array}$} & \multicolumn{4}{|c|}{ Leucine } & \multicolumn{4}{|c|}{ Valine } \\
\hline & & & \multicolumn{2}{|c|}{$\begin{array}{l}\text { 2-Ketoglutarate } \\
\text { aminotransferase }\end{array}$} & \multicolumn{2}{|c|}{$\alpha \mathrm{KIC}$} & \multicolumn{2}{|c|}{$\begin{array}{l}\text { 2-Ketoglutarate } \\
\text { aminotransferase }\end{array}$} & \multicolumn{2}{|c|}{$\alpha \mathrm{KIV}$} \\
\hline & & & Mean & SE & Mean & $\mathrm{SE}$ & Mean & $\mathbf{S E}$ & Mean & $\mathrm{SE}$ \\
\hline Weanling & $35 \mathrm{~g}$ & $\begin{array}{l}0 \\
\text { I } \\
2 \\
3\end{array}$ & $\begin{array}{r}43 \cdot 2 \\
110 \cdot 8 \\
85.4 \\
60 \cdot 3\end{array}$ & $\begin{array}{l}4.75 \\
2 \cdot 55^{*} \\
6 \cdot 2^{*} \\
4 \cdot 7^{*}\end{array}$ & $\begin{array}{l}4 \cdot 0 \\
2 \cdot 3 \\
2 \cdot 6 \\
1 \cdot 6\end{array}$ & $\begin{array}{l}0.6 \\
0.6 \\
0.7 \\
0.25 *\end{array}$ & $\begin{array}{l}44 \cdot 3 \\
94 \cdot 8 \\
56 \cdot 0 \\
-\end{array}$ & $\begin{array}{l}4.95 \\
6.05^{*} \\
1 \cdot 5 \\
-\end{array}$ & $\begin{array}{l}3.4 \\
2 \cdot 7 \\
0.5 \\
0.6\end{array}$ & $\begin{array}{l}0.65 \\
0.10 \\
0.10 * \\
0.05^{*}\end{array}$ \\
\hline Growing & $85 \mathrm{~g}$ & $\begin{array}{l}0 \\
1 \\
2 \\
3\end{array}$ & $\begin{array}{l}5+3 \\
91 \cdot 7 \\
- \\
65 \cdot 9\end{array}$ & $\begin{array}{l}2 \cdot 7 \\
5 \cdot 65^{*} \\
- \\
3 \cdot 9^{*}\end{array}$ & $\begin{array}{l}3 \cdot 9 \\
2 \cdot 5 \\
- \\
2 \cdot 3\end{array}$ & $\begin{array}{l}0.3 \\
0.2 \\
- \\
0.5^{*}\end{array}$ & $\begin{array}{l}43 \cdot 6 \\
58 \cdot 7 \\
- \\
46 \cdot 7\end{array}$ & $\begin{array}{l}4.75 \\
2.80^{*} \\
- \\
4.05\end{array}$ & $\begin{array}{l}2 \cdot 6 \\
2 \cdot 2 \\
1 \cdot 5\end{array}$ & $\begin{array}{l}0.15 \\
0.50 \\
- \\
0.35^{*}\end{array}$ \\
\hline Adult & $200 \mathrm{~g}$ & $\begin{array}{l}0 \\
1 \\
2 \\
3\end{array}$ & $\begin{array}{l}40 \cdot 6 \\
70 \cdot 1 \\
61 \cdot 2 \\
56 \cdot 2\end{array}$ & $\begin{array}{l}4 \cdot 85 \\
9 \cdot 7^{*} \\
3 \cdot 8^{*} \\
5 \cdot 5\end{array}$ & $\begin{array}{l}I \cdot 2 \\
I \cdot 0 \\
0.8 \\
0.9\end{array}$ & $\begin{array}{l}0.04 \\
0.045^{*} \\
0.04^{*} \\
0.06^{*}\end{array}$ & $\begin{array}{l}35 \cdot 3 \\
44 \cdot 8 \\
41 \cdot 3 \\
38 \cdot 8\end{array}$ & $\begin{array}{l}I \cdot 5 \\
2 \cdot 15^{*} \\
0 \cdot 8^{*} \\
I \cdot 3\end{array}$ & $\begin{array}{l}\mathbf{I} \cdot \mathbf{I} \\
0.6 \\
0.7 \\
0.9\end{array}$ & $\begin{array}{l}0.06 \\
0.04^{*} \\
0.10^{*} \\
0.04^{*}\end{array}$ \\
\hline
\end{tabular}

* Values differ significantly from the control value for the group $(P<0.05)$.

was the transient nature of the increase in most groups; frequently the highest level was seen after $\mathrm{I}$ or 2 weeks and by the end of 3 weeks aminotransferase levels were often almost the same as the initial control activities. Thus, after $x-2$ weeks on a PF diet the ratio, aminotransferase:dehydrogenase activity in the homogenates had changed markedly, with an increase in the value from $2-3$ in the control period to $5^{-22 .}$

Measurements of enzyme activities in homogenates of muscle (Table 3 ) confirmed that there was a higher aminotransferase: dehydrogenase ratio in this tissue than in liver (Sketcher et al. 1974). There were similar changes in the weanling and growing rats given the PF diet. Again there was a definite decrease in dehydrogenase activities after I week, with further reduction by the end of 3 weeks on the PF diet. In the oldest group of animals there was a significant decrease in activity but, as in the liver, the change was much less than in the younger animals. Thus, although the initial activity of muscle $\alpha \mathrm{KIC}$ was much higher in the younger animals than in the mature (200 g) rats, once adaptation had occurred, the younger animals showed a greater reduction in activity than those in the oldest group. The aminotransferase activities rose to high levels in the early phase of feeding on a PF diet in all three groups but returned towards normal by the end of the feeding periods. 


\section{DISCUSSION}

\section{Measurement of amino acid oxidation: the choice of technique}

A valid quantitative method for measuring amino acid catabolism is still needed. The rate of oxidation of an essential amino acid is less than the intake since unoxidized amino acid is lost in faecal and cutaneous protein, with a small loss of amino acid in the urine (Aguilar, Harper \& Benevenga, 1972). In a growing animal there is also the need for an additional quantity of amino acid for the formation of new tissue protein. For non-essential amino acids the intake is supplemented by resynthesis of the amino acids and carbon recycling; oxidation rates of non-essential amino acids could, therefore, exceed the dietary intake despite the cutaneous and faecal losses of protein.

Measurements of nitrogen excretion can provide information about the total rate of amino acid oxidation in the body, but unless ${ }^{15} \mathrm{~N}$-labelled amino acids are used the excretion rate is no guide to the catabolism of specific amino acids. Even with ${ }^{15} \mathrm{~N}$ labelling there is the complication of transamination of the labelled amino group (Wu \& Bishop, 1959) and recycling of labelled urea (Picou \& Taylor-Roberts, I969) which limits the value of ${ }^{15} \mathrm{~N}$-labelling as a quantitative measure of catabolism (Read, McLaren \& Tchalian, 197I). For this reason we have chosen $\left[\mathrm{I}^{14} \mathrm{C}\right]$-labelled compounds so that recycling of label is minimized.

The technique employed is similar to that used by McFarlane \& Von Holt (1969a). They, however, administered a tracer dose of DL- $\left[2-{ }^{-14} \mathrm{C}\right]$ leucine which we have shown (Sketcher et al. 1974) gives higher excretion rates of ${ }^{14} \mathrm{CO}_{2}$ than normal because of the rapid deamination and oxidation of the D-isomer. Neale (1972) assessed oxidation of the $\left[\mathrm{U}-{ }^{14} \mathrm{C}\right]$-labelled $\mathrm{L}$-amino acids, but this technique has the drawback that extensive retention of label and incomplete oxidation of the universally labelled carbon chain may occur, particularly when low-protein diets are fed (Reeds, 1974). The present technique using $\mathrm{L}-\left[\mathrm{I}^{-14} \mathrm{C}\right]$ leucine and $\mathrm{L}-\left[\mathrm{I}-{ }^{14} \mathrm{C}\right]$ valine would appear to have some advantages since recycling of label is minimal once the label is evolved as ${ }^{14} \mathrm{CO}_{2}$ (Millward, 1970). Since the label is released in the first step of the catabolic pathway of the carbon skeleton and should gain direct access to the body's carbonate pool, the excretion of ${ }^{14} \mathrm{CO}_{2}$ can be expected to reflect the rate of catabolism of the essential carbon skeleton. The technique, however, cannot be considered to give an absolute measure of amino acid oxidation, since the precursor specific radioactivity will be changing very rapidly after labelling and attempts to quantify the catabolic rate by measuring the pool's specific radioactivity at only one time point would give discrepant results. Relating the proportion of a dose excreted to the preceding dietary intake also ignores the rapid changes in oxidation which might occur during feeding (Brookes, Owens \& Garrigus, 1972). If the free amino pool can be considered as a single amino acid pool, then the percentage of the ${ }^{14} \mathrm{C}$ dose excreted will measure the proportion of the amino acid pool catabolized at the time of measurement. This may then give some indication of the body's mechanisms for amino acid conservation. The quantitative assessment of oxidation rates may prove easier if constant infusions of ${ }^{14} \mathrm{C}$-labelled amino acids are used where the specific radioactivity at the precursor intracellular site for oxidation remains constant and measurable (Neale \& Waterlow, 
1974). If discrepancies between plasma and intracellular specific radioactivity prove small, then in vivo measurements of oxidation in man may also be possible (James, Garlick \& Sender, I974).

\section{Effect of dietary protein restriction on amino acid oxidation}

Our earlier studies on leucine oxidation showed that $65 \mathrm{~g}$ growing rats had the ability to reduce their oxidation of leucine promptly when growth was arrested by the provision of a diet of 0.035 NDp:E (Sketcher et al. 1974). The present results confirm these observations and demonstrate that the ability to conserve branched-chain amino acids does not appear to be age-dependent. Branched-chain amino acid oxidation, therefore, does not seem to be particularly susceptible to a PF regimen in weanling animals, as suggested by the persistently increased oxidation of these amino acids in the previous studies of weanling rats (Neale, I97I). As noted already, these earlier studies with universally labelled compounds may have been complicated by the variable recycling of label so that the effects of protein-free feeding on amino acid oxidation were not discernible (Reeds, I974).

The prompt response in reducing leucine oxidation, assessed with $\mathrm{L}-\left[\mathrm{I}-{ }^{14} \mathrm{C}\right]$ leucine (Table I), was followed by a progressive decrease as PF diet was continued in the younger animals. This progressive decrease was not observed in the oldest group, although McFarlane \& Von Holt (I969a) demonstrated a further adaptive response in similar-sized animals fed on a $20 \mathrm{~g}$ protein $/ \mathrm{kg}$ diet for 8 weeks. This slower but progressive decline in leucine oxidation may only occur in the older animals as tissue depletion begins to approach that seen in the younger rats after 2-3 weeks.

It is also of interest that the fractional excretion rate of isotopic valine is consistently higher $(P<0.05)$ than that of leucine at almost all times on the $\mathrm{PF}$ regimen in weanling rats: this may reflect the more limited ability to conserve valine compared with leucine and could account for the particular tendency of plasma valine levels to fall as dietary protein is reduced in malnourished animals or children (Grimble \& Whitehead, 1970).

\section{Dehydrogenase activity in liver and muscle}

Further support for the reduction in oxidation of leucine and valine in the weanling rats comes from measurements made on the catabolic enzymes responsible for the irreversible decarboxylation of keto acid, i.e. the dehydrogenases. These enzymes were demonstrable in both muscle and liver and reinforced the need to consider both muscle and liver enzymes when evaluating the response to dietary changes. In our earlier studies (Sketcher et al. 1974), feeding a maintenance intake of protein $(0.035 \mathrm{NDP}: \mathrm{E})$ led to changes only in muscle; this tissue accounted for approximately $90 \%$ of the body's capacity for $\alpha$-keto-isocaproic acid oxidation. Although muscle enzymes were more responsive to dietary changes than those in liver, McFarlane \& Von Holt $(1969 b)$ showed a decrease in mitochondrial dehydrogenase activity in liver when a lower protein intake, i.e. $20 \mathrm{~g}$ protein $/ \mathrm{kg}$ diet, was fed. This effect of lower intakes of protein on liver enzymes is confirmed in the present experiments using a $\mathrm{PF}$ regimen. However, the liver dehydrogenase involved in valine catabolism failed 
to adapt as well as that for leucine, which may relate to the more limited reduction in valine oxidation in vivo (Table 2) and gives support to the view that there are two distinct dehydrogenases (Connelly, Danner \& Bowden, I968). When there was no inflow of dietary protein, both liver and muscle seemed to be involved in a concerted effort to reduce leucine oxidation.

Adaptation in the hepatic catabolic enzymes for branched-chain amino acids seems, therefore, to be more delayed and responsive only to dietary extremes; the finer adjustments in leucine oxidation may therefore have been mediated by alterations in their metabolism in muscle. This conclusion must then modify the usual view of the liver as an organ which responds rapidly to dietary alterations with muscle exerting a much less important influence on amino acid metabolism. We have recently shown that muscle is very responsive to dietary intake with a cyclical increase in protein synthesis during the day (Garlick, Millward \& James, 1973) and a rapid decrease in synthesis once protein-free feeding is started (P. J. Garlick, D. J. Millward \& W. P. T. James, unpublished observations). Muscle, despite its lower rate of protein turnover, accounts for a greater proportion of total body turnover of protein than the liver. Thus, the two main metabolic pathways for branched-chain amino acids in the body, i.e. incorporation into protein and oxidation, occur in the same tissue where there may well be a close interrelationship between the two processes.

\section{Aminotransferases}

Ichihara, Noda \& Ogawa (I973) have suggested that the step involving transamination may be the rate-limiting reaction in the oxidation of leucine, particularly in the liver. Clearly, the activity of the enzyme of this reversible reaction is unlikely to be important since not only is its activity much higher than that of several other enzymes involved in catabolism, but the reversibility of this process means that the control of enzyme activity itself is unlikely to be an important process determining oxidation rates (Brown, Houghton, Souhami $\&$ Richards, 1972). This conclusion is reinforced by the present work demonstrating a dissociation between the changes in aminotransferase activity and the rate of amino acid oxidation. Thus, the highest aminotransferase activities were seen on PF diets with low rates of leucine catabolism. Transamination, however, could be affected by the supply of substrates or the rate of removal of transamination products. There is evidence from experiments with liver slices to suggest that transamination is dependent on the addition of $\alpha$-ketoglutarate (Dawson, Hird \& Morton, 1967), and Ichihara et al. (1973) have also concluded that in liver, but not in kidney, transamination is a rate-limiting step. Recently Walser, Lund, Ruderman \& Coulter (I973) have demonstrated that both perfused liver and muscle can re-aminate the branched-chain amino acids from their $\alpha$-keto acid analogues. The increased activities of the aminotransferases in both liver and muscle (in protein-depleted animals) are consistent with the generation of amino acids if intracellular concentrations of the $\alpha$-keto acids increase. Re-amination in situ, as well as exchange of $\alpha$-keto acid between tissues, may then conserve the essential carbon skeleton. A perfused hind-limb preparation is being used for further studies of this problem. 


\section{REFERENCES}

Aguilar, T. S., Harper, A. E. \& Benevenga, N. J. (I972). F. Nutr. I02, I 199.

Brookes, I. M., Owens, F. N. \& Garrigus, U. S. (1972). F. Nutr. 102, 27.

Brown, C. L., Houghton, B. J., Souhami, R. L. \& Richards, P. (1972). Clin. Sci. 43, 37 .

Buse, M. G., Biggers, H. F., Friderici, K. H. \& Buse, J. F. (1972). f. biol. Chem. 247, 8085.

Connelly, J. L., Danner, D. J. \& Bowden, J. A. (I 968). F. biol. Chem. 243, I 98.

Dawson, A. G., Hird, F. J. R. \& Morton, D. J. (1967). Archs Biochem. Biophys. r22, 426.

Featherston, W. R. \& Horn, G. W. (1973). F. Nutr. ro3, 757.

Garlick, P. J., Millward, D. J. \& James, W. P. T. (1973). Biochem. J. r36, 935.

Goldberg, A. L. (1972). In Muscle Biology Vol. I, p. 98 [R. G. Cassens, editor]. New York: M. Dekker Inc.

Grimble, R. F. \& Whitehead, R. G. (1970). Br. F. Nutr. 24, 557.

Ichihara, A., Noda, C. \& Ogawa, K. (1973). In Advances in Enzyme Regulation Vol. I1, p. I55 [G. Weber, editor]. New York: M. Dekker Inc.

James, W. P. T., Garlick, P. J. \& Sender, P. M. (1974). Clin. Sci. mol. Med. 46, 8p.

McFarlane, I. G. \& Von Holt, C. (I969a). Biochem. F. III, 557.

McFarlane, I. G. \& Von Holt, C. (1969b). Biochem. F. Irr, 565.

Miller, L. L. (1962). In Amino Acid Pools p. 708 [J. T. Holden, editor]. Amsterdam: Elsevier.

Millward, D. J. (1970). Clin. Sci. 39, 591.

Mimura, R., Yamada, C. \& Swendseid, M. E. (r968). J. Nutr. 95, 493.

Neale, R. J. (1971). Nature New Biol. 23ז, I I7.

Neale, R. J. (1972). Biochim. biophys. Acta 273, 8o.

Neale, R. J. \& Waterlow, J. C. (1974). Br. F. Nutr. 32, I I.

Pain, V. M. \& Manchester, K. L. (I970). Biochem. F. 118, 209.

Payne, P. R. \& Stewart, R. J. C. (I972). Lab. Anim. 6, I35.

Picou, D. \& Taylor-Roberts, T. (1969). Clin. Sci. 36, 283.

Read, W. W. C., McLaren, D. S. \& Tchalian, M. (I97I). Clin. Sci. 40, 375.

Reeds, P. J. (1974). Br. F. Nutr. 31, 259.

Ruderman, N. B. \& Lund, P. (1972). Israel F. med. Sci. 8, 295.

Sketcher, R. D., Fern, E. B. \& James, W. P. T. (r974). Br. F. Nutr. 3r, 333.

Walser, M., Lund, P., Ruderman, N. B. \& Coulter, A. W. (1973). F. clin. Invest. 52, 2865.

Wolhueter, R. M. \& Harper, A. E. (1970). F. biol. Chem. 245, 239 I.

Wu, H. \& Bishop, C. W. (1959). F. appl. Physiol. 14, r.

Young, V. R. (1970). In Mammalian Protein Metabolism Vol. 4, p. 612 [H. N. Munro, editor]. New York and London: Academic Press. 